\title{
Empati Kavramına Bauman Çerçevesinden Bir Bakış¹
}

\author{
DOI: 10.26466/opus.570549
}

\author{
Doğa Başer* - Mehmet Kırlığlu** - Huriye İrem Kalaycı Kırlıoğlu ${ }^{* * *}$ \\ *Dr. Öğr. Üyesi, Selçuk Üniversitesi Üniversitesi, Sağlık Bilimleri Fak. Konya/Türkiye \\ E-Posta: baserdoga@gmail.com ORCID: 0000-0002-7451-6590 \\ **Dr. Öğr. Üyesi, Necmettin Erbakan Üniversitesi, Sağlık Bilimleri Fak. Konya/Türkiye, \\ E-Posta: kirlioglumehmet@gmail.com ORCID: 0000-0003-0130-0841 \\ *Dr., Selçuk Üniversitesi Üniversitesi, Sağlık Bilimleri Fak. Konya/Türkiye \\ E-Posta: hurirkal@gmail.com \\ ORCID: $\quad \underline{0000-0002-8352-8868}$
}

\section{Öz}

Ötekini anlamak ve onu hissedebilmek sosyal bilimlerin temel uğraşlarından biri ve çıkmazı haline gelmiştir. Disiplinler arası bir genel kabul olarak empati, karşıdaki kişinin hissettiklerini ve düşündüklerini zihninde canlandırabilme yeteneğidir. Empatinin duygu ve düşüncelerin anlaşılmasına vurgu yaptı̆̆ı düşünüldü̈̆̈̈̈nde Bauman'ın da eserlerinde duyguları yoğun bir şekilde ele aldığg görülür. Bu çalışmada güncel empati literatürü Bauman'ın görüşleri çerçevesinde değerlendirilmiştir. Bu çerçevede rasyonellik, ahlak, biz ve onlar temaları değerlendirmeye alınmıştır. Rasyonellik temasında empatinin bilişsel ve duygusal boyutlarının bir arada bulunmasından hareketle Bauman'ın rasyonellik eleştirisi ele alınmış, rasyonellik ile empatinin bilişsel boyutu arasında ilişki kurularak ötekini anlamada bilginin ve hissetmenin önemine değinilmiştir. Ahlak temasında Bauman'ın ahlaki yaklaşımında temel gösterdiği Levinas'ın ahlak anlayışı çerçevesinde ötekini anlamanın imkanı ve bunun özgecilikle ilişkisi değgerlendirilmiştir. Empati günümüzde yardım etmenin ve özgeci davranışın önemli bir kaynağı olarak görülmektedir. Bununla birlikte empatide kişinin ötekini anlamaya çalışırken olumsuz etkilenmemek için kendine sinırlar koymasının altı çizilmektedir. Biz ve onlar temasında ise toplumsal yaşamdaki gruplaşmaların ötekini anlamayı ne derece etkilediği değerlendirilmiş, ötekini anlamanın benzerlik, yakınlık ve farklılıkla ne gibi ilişkileri olabileceği üzerinde durulmuştur.

Anahtar Kelimeler: Zygmunt Bauman, Empati, Ahlak, Özgecilik, Rasyonellik.

\footnotetext{
${ }^{1}$ Bu çalışma 19-21 Mayıs 2017 tarihlerinde yapılan I. Uluslararası Zygmunt Bauman Sempozyumu'nda özet bildiri olarak sunulmuştur.
} 


\title{
The Concept of Empathy Through the Perspective of Zygmunt Bauman
}

\begin{abstract}
Understanding and feeling the other have become one of the main pursuits and dead ends of social sciences. The multidisciplinary conception of empathy is the ability of envisioning of what the other thinks and feels. Considering the fact that empathy emphasizes understanding of feelings and thoughts, Bauman gives also a strong emphasis on emotions. This study evaluates the current literature of empathy within the context of Bauman's ideas. The themes of rationality, morality, us and them are evaluated in this context. Within the theme of rationality, Bauman's criticism of rationality evaluated depending on the fact that empathy has both cognitive and emotional aspects. Similarly, the relation between empathy and rationality is formed with which the importance of knowledge and feeling are mentioned in understanding the other. In the theme of morality, Levinas' understanding of morality, which is the foundation of Bauman's morality, is used to analyse the possibility of understanding the other and its relation to altruism. Nowadays, empathy is seen as a source of helping the other and altruistic behavior. The discussions of empathy also underlies the importance of human beings' limitations of themselves to protect themselves from being negatively affected while they are trying to understand the other. This conception of altruism includes human beings' giving priority to the other before themselves. For the themes of we and the other, the scope of influence of grouping in social life for understanding the other, and what kind of relation might be between understanding of the other and being similar, close and different are the subjects that are emphasized.
\end{abstract}

Keywords: Zygmunt Bauman, Empathy, Morality, Alturism, Rationality. 


\section{Giriş}

Empati kişilerarası ilişkilerde ve sosyal etkileşimde kritik bir rol oynamaktadır. Son yıllarda sosyal psikoloji, gelişimsel bilim ve bilişsel nörobilim dahil olmak üzere çeşitli akademik alanlarda empati bir ilgi alanı haline gelmiştir (Decety ve Moriguchi, 2007). Empati araştırmalarının en önemli niteliği insan davranışını ve insanın sosyal gelişimini anlamaya ve açıklamaya çalışan farklı disiplinleri ve teorik bakış açlarını birleştirmesidir (King, 2011). Empatinin duygu ve düşüncelerin anlaşılmasına vurgu yaptığ1 düşünüldüğüne Bauman'ın da eserlerinde duyguları yoğun bir şekilde ele aldığı görülür. Korku, güvensizlik, belirsizlik, aşk, sevgi, çaresizlik, hassasiyet, vicdan, mutsuzluk ve kaygı temaları Bauman'ın metinlerinde sıkça vurgulanmaktadır. Toplumsal olguların nasıl bir his bıraktığı, içeriden nasıl algılandığı ve deneyimlendiği onun metinlerinde ön plana çıkmaktadır (Bauman, 2017, s.137). Bu çerçevede kişilerin gündelik hayatlarındaki rutin eylemleri sırasında hissettikleri Bauman'in sosyolojisinin konusu olmaktadır (Blackshaw, 2005, s.3). Bauman metafor kullanımıyla insan deneyimine özgü anlamları ve deneyimleri incelemeye çalışır. Onun anlatımında metaforlar insanların deneyimlerinin duygusal boyutunu da yansitmaya dikkat eder. Örneğin "marjinal" ya da "marjinalleşmiş kişi" kavramı bir fenomenin sadece bilişsel boyutuna gönderme yapar. Oysa ki Bauman'ın kullandığı "wasted" ve "wasted lifes" (atık, boşa harcanmış hayatlar) metaforu marjinalliği deneyimlemenin duygusal boyutunu ve marjinal insanların hissettiklerini de içermektedir (Cosmovici, 2016). Nitekim Bauman Consuming Life'da tüketim toplumunda kişilerin mutlu olmak için daha çok para harcadıklarını, aşk ilişkilerini maddileştirdiklerini fakat karşılıklı empatiyi kuramadıklarını belirtmektedir (Bauman, 2007a, s.121). Cosmovici'ye göre (2016) Bauman'ın metaforik anlatımı sosyolojinin yanı sıra psikoloji için de ilgi çekicidir, çünkü sosyal bilimlerin küreselleşmenin hızlı değişimleri ile yüzleşmesi sonucu insanların psikolojileri ve duygusal durumları önem kazanmaktadır. Bu noktada ne yazık ki sosyoloji teorilerinde duyguların ikinci planda kalması önemli bir eleştiri olarak göze çarpmaktadır. Nitekim Mestrovic (1999) Duyguötesi toplum adlı eserinde duyguların rolünün sosyoloji de 'kayıp malzeme' olarak yer aldığını belirtmektedir. 
Bu çalışmanın amacı rasyonellik ile empatinin bilişsel boyutu arasında ilişki kurarak ötekini anlamada bilginin ve hissetmenin, ikinci olarak Bauman'ın ahlaki yaklaşımında temel gösterdiği Levinas'ın ahlak anlayışı çerçevesinde ötekini anlamanın imkanı ve bunun özgecilikle ilişkisinin, son olarak ise toplumsal yaşamdaki gruplaşmaların ötekini anlamayı ne derece etkilediğinin değerlendirilmesidir. Bu çerçevede güncel empati literatürü Bauman'ın görüşleri çerçevesinde tartışılarak rasyonellik, ahlak, biz ve onlar temaları değerlendirmeye alınmıştır.

\section{Rasyonellik}

Sosyoloji ve felsefe literatürüne yönelik bir değerlendirme yapıldığında bir çok metinin modernlik ve rasyonelliği kendine konu edindiği görülmektedir. Modern toplumdaki rasyonelleşme eğilimine yönelik ilk eleştiriler bizzat modernliğin doğuşuna tanık olan Rousseau'dan gelmiştir (Kumar, 2004, s.115). Bunun yanında modernliğin toplumsal yaşamdaki sonuçları, birçok düşünürün ilgi konusu olmuştur. Özellikle "Nietzsche, Heidegger, Simmel, Weber ve Adorno'nun çalışmaları" modern aklın sonuçlarına yönelik eleştirel değerlendirmeleri barındırmaktadır (Smart, 2000, s.318). Bu değerlendirmeler, günümüz felsefi-sosyolojik söylemine bir temel oluşturmaktadır.

Bauman'ın yapıtlarında rasyonelliğin modernlikle ilişkili bir şekilde ele alındığı görülmektedir. Rasyonelliğin temel unsurlarından biri "doğru sonuçlara hızlı ve ucuz bir biçimde varmaktır" (Bauman, 2003, s.70). Modern etkinlik "aklın duygular, rasyonel davranışın irrasyonel güdüler üzerindeki üstünlügünü" vurgular (Bauman, 2003, s.132). Bauman perspektifinde akıl "insanın bilme, tahmin etme, hesaplama" yeteneğidir (Bauman, 2010, s.98). Empati ve rasyonellik açısından özellikle ikinci dünya savaşındaki soykırımlar çerçevesinde rasyonelliğin duyarsızlaşma açısından tehlikeli bir olgu olduğu belirtilmektedir. Nazi subaylarının hissiyatları ya da hissiyatsızlıkları Bauman'ın sıklıkla üzerinde durduğu bir konudur. Gruen (2006, s.11) soykırımı empati ile bağlantılandırarak "Auschwitz, başkasının duygularını anlamaktan aciz insanın ne denli yozlaşabileceğini gözler önüne seren uyarıcı bir örnektir" ifadesinde bulunmaktadır. Mestrovic de (1999) Duyguötesi Toplum adlı eserinde günümüz insanının öfkeden tutkuya kadar çok geniş skalada duyguları 
hissedebildiğini fakat bu hisleri eyleme dökme noktasında pasifize olduğunu belirtir ve durumu Bosna Savaşı'nda NATO'nun ilgisizliği ile birlikte tartışır. Duyguötesicilik bu bağlamda yapılanların bilinmesi hissiyatın olması ama eyleme geçmemeyi de ifade eden bir duygu-eylem kopukluğuna gönderme yapar. Bauman'a göre (2001) akıl ve duygusallık çiftleri zaten birbirine olan karşıtlıkları sayesinde anlam kazanmaktadır. Akıl, kural merkezli yapısıyla kuralsızlığa gönderme yapan duygusallığı dışlamaya çalışır. Bauman modernliğin aklı yücelterek duygusallığı dışladığını belirtir. $\mathrm{O}$, duygular ve rasyonellik arasında en genel ayrımı "aşk ile akıl birbirine zıt iki kutbu ifade eder, aşk değere, akıl ise faydaya ilişkindir. Akıl aşkın belirsizlik ve saptanamazlık özelliklerine tahammül edemez. Ayrıca aşk ötekiyle dayanışmayı gerektirirken, akıl sürekli olarak benliğe sadakat duymayı önerir" (Bauman, 2005, s.206) ifadeleri ile gündeme getirmiştir.

Bauman'ın argümanlarını empati açısından değerlendirdiğimiz de ise literatürde empatinin bilişselliği (rasyonelliği) ve duygusallığ farklı argümanlar olduğu görülmektedir. Empatinin rasyonel bir arka plana mı dayandığı yoksa duygusal bir temele mi sahip olduğu tartışmalı bir konudur. Güncel empati araştırmalarının temel bulgusu iletişim sürecine paralel bir şekilde karar verme yetimizin yalnızca mantıksal bir hesaplamadan ibaret olmadığı, duyguların da önemli bir rol oynadığına yöneliktir (Gerdes, 2011). İnsanın varlığını sürdürmesi başkaları ile olan sosyal etkileşimlere bağlıdır. Ancak insanların kendi düşünümsel ve esnek muhakeme olanakları vardır. Bu temel duygu süreçlerinin yaşamımızda bir rol oynamadığını ifade etmekten ziyade, duyguların muhakeme yeteneğimize entegre olduğu anlamına gelmektedir (Decety ve Moriguchi, 2007). Empatinin kişiler arası ve dinamik bir yapısı olmasından dolayı aslında onu duygusal, bilişsel ve davranışsal olarak ayrışmış şekilde tahayyül etmek zordur. Bazen aynı anda düşünür hisseder ve yaparız, bir iç içe geçmişlik söz konusudur (King, 2011, s.687). Hakansson ve Montgomery (2003) empati kurma sürecinde empati kuran kişinin yaptı̆̆ şeyi temsil etmek üzere "anlamak", "dünyasına girmek", "paylaşmak" ve "tahayyül etmek" gibi kavramların kullanıldığını vurgulamaktadır. Duyguyu bir öncelik haline getiren Levenson ve Ruef (1992) empatide kişinin duygularını doğru olarak algılayabilme kabiliyetinin en temel boyut olduğunu, başkasının duygularını doğru olarak anlamadan 
başkasının hissettiğini hissetmek ya da ona şefkatle cevap vermenin zor olacağını belirtmektedir.

Empatinin sadece rasyonel bir sürecin ifadesi olmadığ özellikle olumsuz insanlık durumlarından duygusal olarak etkilenme açısından belirtilmektedir. Literatürde McCann and Pearl (1990) aracilı travmatizasyon (vicaorus trauma), ikincil travmatizasyon (secondary traumatic stress) ve merhamet yorgunluğu (compassion fatigue) kavramlarının genel olarak yardım profesyonellerinin travmatize kişilerle çalışırken devamlı olarak travmatik hikayelere ve görüntülere empatik olarak maruz kalmaları sonucu kendilerinde post travmatik stres bozukluğu belirtileri görülmesi sürecini ifade ettiğini vurgulamaktadır (Thomas ve Otis, 2010). Travma yaşamış insanlarla yakın ilişkide olmak ve bundan yoğun olarak etkilenmek empatinin basitçe rasyonel-bilişsel bir temel ile anlaşılamayacağının göstergesidir. Burada kullanılan "yakın ilişkide olmak", "etkilenmek" kavramları kuşkusuz Bauman'ın örneklediği Milgram deneyini akla getirmektedir. Nitekim Milgram'ın deneyi fiziksel yakınlık duygusunun en çok gözler ile oluştuğunu ortaya çıkarmıştır. Fiziksel temasta olduğumuz birine zarar vermemiz zor ve bizi etkileyen bir süreç iken uzaktan gördügümüz ya da sadece sesini duyduğumuz birine zulmetmek ise nispeten daha kolay (Bauman, 2007b, s.210) olması insanlık durumlarından olumsuz etkilenmeye yönelik doğamızın rasyonellik ile nasıl da alt edilebileceğine vurgu yapmaktadır.

\section{Ahlak}

Bauman ahlakı insanlar arası ilişki, dayanışma ve sorumluluk bağlamında değerlendirilir. Onun perspektifinde ahlak kişilerden karşıllık talep etmeden yardım etmeyi, ötekinin refahını düşünmeyi, bunun için kişisel refahına sinırlama getirmeyi ve kendinden feragat etmeyi ifade eder (Bauman, 2004, s.148). Bauman empati ve ahlak arasında bağlantı kurar. Empatik duruş kişinin tek başına kaldığ kişisel bir duruştur, ki bu duruş kararsızdır, iyi-kötü kodları belirlenmiş bir etikten uzaktır. Belirli kodlarla ve normlarla belirlenmiş bir etiğin yaşam alanında ötekinin acısına ve bunların paylaşılmasına yer yoktur (Bauman, 2001, s.81). O duyguların ahlak açısından işlevlerini şöyle özetler (Bauman, 2001, s.81): Öncelikle duygular insanlar arası ilişkilerin nesneler boyutunda yaşanmasına sebep 
olan kayıtsızlığı engeller; ikinci olarak insanlar arası ilişkilerdeki stereotiplere karşı çıkarak sorgulama ve açıklığa imkan verir; son olarak duygular, ötekini normatif, evrensel kuralların alanından çıkararak etiğe meydan okur. Empati literatüründe de ahlaki duyarlılıkla empati arasında ilişki kurulduğu görülmektedir. Nitekim Carse (2005, s.173) doğru ahlaki duyarlılığın sıklıkla empatiyi gerektirdiğini belirtmektedir. Ciddi bir hastalığa yakalandığını öğrenen bir kadının durumu burada örneklenebilir. Bu kadının kaygılı olduğu çok kolay söylenebilir ama bu kaygının karakteri tam olarak nedir? Bir korku ya da keder mi? Bunların karışımı m? Bu kadın acı çekeceğinden ya da öleceğinden korkabilir. Belki ailesinde kendine bağımlı olanların bakımı ile ilgili suçluluk yaşayabilir ya da zaten meşgul olan ailesine bir yük çıkarmanın suçluluğunu yaşayabilir. Zayıf ve muhtaç olmaktan korkabilir

Bauman ahlakı toplumsal bağlamla ilişkilendirir. Ona göre "ahlaksal tavır ancak, başkalarıyla birlikte olmanın koşullarında, yani toplumsal bağlamda anlaşılabilir" (Bauman, 2007b, s.241). Buradaki toplumsal bağlam öteki ve sorumluluk çerçevesinde anlaşılmalıdır ki özgeci birliktelik biçimi bu noktada empati ile bağdaştırılacak bir boyuttur. Özgeciliğin en gündemde olan kavramsallaştırması, olaydan yarar görecek olan ya da görmesi muhtemel olan bireyin kazancı için, yarar sağlayan davranışta bulunan bireyin kendisini düşünmeden hareket etmesidir. Yani yardım eden kişinin bu davranıştan herhangi bir karşılık beklememesi durumudur. Özgecilik genellikle olumlu sosyal davranış ya da yardımsever davranış olarak nitelendirilmektedir (Karadağ ve Mutafçılar, 2009). Bauman ahlaki yaklaşımında Emanuel Levinas'ı temel alır. Levinas'a göre insan olmanın en temel niteliği başkaları ile birlikte olmaktır, bu da ancak sorumluluk almak ile mümkün olabilir (Bauman, 2007b, s.244). Levinas'ın düşüncesinde özne dünyanın bir yaratıcısı rolünde değildir, dünya özneden bağımsız ve öznenin dışında yer alan bir durumdadır. Özne dış dünya ile ancak sorumluluk alarak bir ilişki kurabilir (Bauman, 2010, s.40). Levinas'ın düşüncesinde akıl ve bilme bir ihtiras teması olarak ön plana çıkar ki bu nokta da çalışmanın başında bahsedilen başkayı anlamanın bilişsel ve duygusal boyutuna gönderme yapar. Levinas başkayı anlayabilme açısından aklı ön planda tutmaz ve aklın totaliterliğini vurgular. Levinas'a göre Batı temelli felsefe, kendi perspektifi çerçevesinde bütün dünyayı anlamlandırabildiğini ifade eder, diş 
dünyayı kendi paradigması içine çekmeye çalışır (2010, s.163). Şeyleri, ya kendi söyleminin içinde aynılaştırır ya da farklı olarak dışlamaya çalışır. Böylece akıl ile kavranan dünyadaki 'başka'lıklar yok olmaya yüz tutar. Batı'nın akla yaptığı vurgu ile oluşan 'başka'yı anlama etkinliği, 'başka'yı kendine benzetir (2010, s.131). Levinasta başka ile olan ilişki öncelikle Husserl'in fenomenoloji anlayışını eleştirerek gün yüzüne çıkar. Husserlci çerçevede empati başka insanları algılayabilmenin anahtarıdır. Bununla birlikte buradaki temel nokta onu benzerlik temelinde algılamaktır, yani diğer insanları bana benziyormuşcasına algılarım. Başka insanlarla onların bana benzediği oranda iletişim kurabilirim, burada doğrudan bir aynılaştırma olmasa da benzer yanların varlığı ön plana çıkar (Apaydın, 2006). Bu çerçevede Turan'inda ifade ettiği üzere 'başka'yı 'aynı'ya indirgeme süreci içerisinde bulunulmaktadır. Etik öznellik de sorumluluğun tam bu anlamında kurulur ve bozulur. Özne kendini bir anda öteki olana bağlı bulur. Levinas'taki yerinde olma durumu Husserlci anlamda bir empati değildir. Tersine; öznenin kökensizliği, konumsuzluğu ve anarşikliğidir" (Turan, 2016).

Vignemont ve Singer (2006) empatinin iki önemli rolü olduğunu ileri sürmektedir. Birincisi epistemolojik rol; diğer insanların gelecekteki eylemleri ve önemli çevresel özellikleri hakkında bilgi sağlamasıdır. Bu anlamda empati dünya hakkında bize bilgi sağlar. Bilgiye dayalı bu anlayış Bauman'ın temel aldığı Levinascı dünya görüşüne zıt bir yaklaşımdır. Nitekim Levinascı felsefe insanlar arası etkileşimde bilmeyi amaç haline getirmez ve anlamayı aşan bir noktaya dikkat çeker. Levinas'a göre, "başkaya sahip olunabilseydi, başka yakalanabilseydi, bilinebilseydi, başka olmazdi. Sahip olmak, bilmek, yakalamak iktidarla eş anlamlıdır (Levinas, 2005, s.119). Başkalığın yok edilmesi despotizmdir ve bu paradigma ötekini anlayamaz. Sonuç olarak "başka ile ilişki gizem ile bir ilişkidir (Levinas, 2005, s.102).

Hookway (2016) Bauman'ın öteki kavrayışını Sara Ahmed'in düşünceleri çerçevesinde değerlendirmektedir. Ona göre öteki soyut, belirsiz ve erişilemeyen bir noktada olan ve bir kaygı unsuru değildir aksine öteki duygu paylaşımında ve ilişkide bulunduğumdur. Bu nokta özellikle ötekinin bir vücut bulması ve ötekine yaklaşımımızın ilişkilerimiz ve duygularımız tarafından şekillendiğini vurgulaması açısından önemlidir. Buradan başka ile olan ilişkide onu anlamayı içermemesi anlamı 
çıkarılmamalıdır."Başkasıyla olan ilişkimiz, elbet onu anlamayı istemektir; ama bu ilişki anlamayı aşar" (Levinas, 2005, s.80). Başkası ile ilişkinin gizemine yönelik empati literatüründe de sınırların olduğu belirtilmektedir. Başkasının deneyimi kendi bakış açımızdan hiç bir zaman tam olarak anlayamayız. Bu konuda kendi limitlerimizi kabullenmeliyiz. Bununla birlikte başkalarının deneyimlerini empati kurarak anlamaya ihtiyacımız vardır. Nitekim Hardy ve Mawhiney (2000, s.20) empatinin insanlara yardım ederken kendi egosantrik bakışımızın ötesine geçmemize izin verdiğini belirtirken Freedberg (2007) ise insanların farklı ve karmaşık olduğunu, başkasının öznel ve bilişsel deneyimlerine ulaşma noktasında kusursuz empati diye bir şeyin olmayacağını vurgulamaktadır. Bu bağlamda empati anlama uğraşı ile birlikte yanlış anlama ihtimalini de bünyesinde barındırır

Vignemont ve Singer (2006) empatinin ikinci önemli rolünün ise sosyal rol; etkili sosyal iletişimin yanı sıra dayanışmacı ve özgeci davranışlar için motivasyon temeli sağlaması olduğunu belirtmektedir. Örneğin başka bir kişinin empatisini algılamak bu kişi ile duygusal bağ kurmak ve güçlenme açısından önemlidir. Empatinin insanlar arası ilişkide güveni tesis eden bir araç olduğu literatürde vurgulanmaktadır. Özellikle Carl Rogers (2011, s.506) empatik bir anlayışın kişiyi kabullenmede önemli bir başlangıç olduğunu belirtir "Sizi empatik olarak anlıyorsam; sizi, hissettiklerinizi ve yaptıklarınızı sizin bakış açısından görüyorsam; özel dünyanıza giriyor ve onu sizin gözlerinizden görüyorsam ve tüm bunları kabul ediyorsam, işte o zaman güvenlik tesis edilmiş demektir". De Waal'ın da belirttiği üzere (2008) empati başkasının acısına, sıkıntısına ya da ihtiyaçlarına yönelik özgeci tepkiler vermenin altında yatanları açıklayan en uygun aday olarak değerlendirilmektedir. Empati kaynaklı özgecilik kaynağını başkasının refahından gelen duygusal tatminden almaktadır. Goleman'a göre empati (2006, s.267) "kendimizinkinden ziyade başkalarının ihtiyaçlarını karşılamaya odaklanan şefkatli bakımda ana rolü oynar. Geniş kapsamlı bir terim olan şefkat, günlük hayatta erişilebilirlik, duyarlılık veya karşılık verme istekliliği olarak kendini gösterir". Segal (2011) empatinin özgecilik ve dayanışma ile ilişkili olduğunu belirtmekte iken; Dökmen (1998) e göre "Ben-merkezcilik ve empatik anlayış birbirleriyle bağdaşmaz. Ben merkezci davranan bir kişinin, karşısındakinin rolüne girmesi ve olaylara onun bakış açısından bakması, yani 
empati kurması mümkün değildir." Bununla birlikte her özgeci davranışın arkasında empatinin bulunmasının mümkün olmadığı da unutulmamalıdır İnsanlar bir çok sebepten (kişisel ödül, tatmin, sempati, suçluluk, ya da diğer egoistik motivasyonlardan) iyi şeyler yapabilir (Gerdes ve Segal, 2009, s.116). Empati ve özgecilik açısından temasına Levinas'ın perspektifinden bakıldığında Levinas'a göre özne, "ötekini buyur etmek, konukseverlik olarak" ön plana çıar, burada herhangi bir bilme ilişkisinin tersine, bilinmezlik durumuyla paralel giden, sınır çekemeyen bir sonsuzluk durumu vardır (2010, s.97). Onun kurguladığı özne, hislenen, etkilenen bir öznedir ve "radikal özgecilik" niteliğini taşır (CalinSebbah, 2011, s.46-55). Levinas'a göre söz konusu özgecilik kendinden önce başkasına öncelik vermeyi içerir (2010, s.247). Çünkü başka "yoksuldur, yoksundur" (2010, s.23) ve başkaya yönelik sorumluluk, herhangi bir sınırı barındırmaz, sonsuz nitelik taşır, kaygı konusu olur; sorumluluk özgürlükten önce gelir ve herhangi bir yasa-sözleşme dayanağını temel almaz (2010, s.81). Burada sonsuzluk, "düşünülenden fazlasını düşünme"yi ifade eder ve "vicdan rahatlığını" imkânsız hale getirir (2010, s.124).

Vicdan rahatlının imkansızlığı dile getirildiğinde ilk olarak empatisempati-merhamet kavramlarının tartışmaya dahil olduğu görülmektedir. Sempati kavramı merhamete olan vurgusuyla da ön plana çıkmaktadır. Sempati kişide kaygı uyandırabilen ve karşı tarafın durumunu düzeltmeye yönelik bir isteği ifade eden bir kavramdır (De Waal, 2014). Bu çerçevede sempati kavramının acıma, merhamet, şefkat ile daha çok ortak noktası vardır (Egan, 2010). Merhamet başkalarına şefkat göstermektir fakat bu acıma hissi ile sinırlıdır (Segal, 2007). Nitekim Vignemont ve Singer (2006) empatiye yönelik tanımlamaların geniş ve dar olmak üzere iki farklı boyutta sınıflandırılabileceğini, geniş tanımlamaların sempati, kişisel sıkıntı ve duygusal etkilenmeyi de içerirken dar tanımlamaların bu derece kapsamlı olmadığını belirtmektedir. Sempati kavramı başkası için acı ve üzüntü hissetme (Decety ve Moriguchi, 2007), başkasının duygusal durumunu hoş görmek ve desteklemek (Hepworth ve ark, 2010), karşıdaki insanın duygu ve düşüncelerine aynen sahip olmak, kişi ile birlikte acı çekmek sevinmek, o kişinin yandaşı olmak ve ona hak vermek (Dökmen, 1998), karşısındakinin sorununu içselleştirmek (Tarhan, 2013) niteliklerini bünyesinde barındırmaktadır. Burada 
empatiyle yakın bir ilişki mevcut olsa da keskin ayrımların da varlığ1 vurgulanmaktadır. Empatide duyguların paylaşımı vurgulansa da kişi kendi duygularıyla karşıdaki kişinin duygularını açık bir şekilde ayırt edebilir (Vignemont ve Singer, 2006). Empati, başkasının hislerini anlama noktasında ben ve başkası arasında net sınırlara sahiptir. Empatik tepki bir kişinin deneyiminin anlamını yakalamak için çabalarken, deneyimin yoğunluğunun kişiyi etkilemesine karşı kişiyi koruması ile ön plana çıkar (Dyche ve Zayas, 2001). Bu noktada Bauman'ın sorumluluk anlayışı temelli ilişki biçiminin empatiye mi sempatiye mi daha yakın olduğu sorunsalı ortaya çıkmaktadır. Empatide önemli noktalardan biri de duygu düzenlemesi yani kişinin kendi duygusal deneyimlerini değiştirmesi ya da kontrol etmesidir. Bazen başkasının hissettiğini hissetmek çok yoğun, baskılı olabilir ve bu durumda bakış açımızı kaybedebiliriz. Bu sebeple gereğinden fazla özdeşim kurabiliriz ya da aramızdaki sınırların kalktığı bir durum yaratabiliriz (Gerdes ve Segal, 2009, s.119). Merhamet açısından ise Morgan ve Morgan (2005) merhamet-empati ilişkisine farklı bir boyuttan yaklaşmakta ve iki kavram arasında farklılık olsa da merhamet ve empatinin "iyilik" çatısını paylaşan iki kavram olduğunu ifade etmekte, Goleman ise (2006) empatinin şefkatle olan bağlantısına değinerek şefkat ve empatiyi günlük yaşamdaki sosyal ilişkilerde insanların temel arayışlarından biri olarak değerlendirmektedir

Levinas'ın vurguladığı başkanın yoksul ve yoksun olmasının onun bir rehine gibi sorumluluğu alınacak bir çerçevede değerlendirilmesi bir anlamda başkanın üzüntüsünü paylaşmanın sevincin paylaşılmasından daha önemli olduğunu ifade eder niteliktedir. Buna paralel şekilde Royzman ve Kumar (2001) da literatürde empatinin kavram olarak nötr bir değer taşıdığını yani hem pozitif hem de negatif duyguları aynı derecede hissetmeyi vurguladığını, oysa negatif empatik cevapların çok daha yaygın, farklılaştırılmış ve çok daha geniş bir çerçevede insan ilişkilerinde bulunduğunu belirtmektedir. Bazı öncelikli insan ilişkileri dışında birinin kötü oluşunu paylaşmamak iyi oluşunu paylaşamamaya göre daha çok acı verir. Ayrıca negatif olaylara karşı daha yoğun empati eğilimimiz belki de toplumun ortak ahlakında bulunan pozitif-negatif asimetrisinin temelidir. Özellikle birinin zevk alışının arttırılmasından çok birisinin acısının azaltılması çok daha önemli bir ahlaki iddiadır. Burada ikinci değerlendirilecek konu başkanın sorumluluğunu almanın kişiyi nasıl 
etkileyebileceğine yöneliktir. Hakkansson ve Montgomery (2003, s.282) empati ilişkisinde kendisiyle empati kurulan hedef kişinin empati kuran kişiye göre daha olumlu bir deneyim yaşadığını vurgulamaktadır. Bu özellikle hedef kişinin sorunlu bir durumuna yönelik kendisine destek verilmesi, yardımcı olunması veya anlaşıldığını hissetmenin etkisi olarak düşünülebilir. Empati kuran kişiler ise daha çok hedef kişinin olumsuz deneyimlerinin verdiği stresten etkilenmektedirler. Sonuç olarak empati kuran kişi için empati zaman, dikkat ve empati kurmak için çaba harcama diyebileceğimiz "yardımın bedeli"ne dönüşmektedir. Tekrar Levinas'a dönersek onun ben-öteki ilişkisi empatiyi aşan bir çerçevede değerlendirilmektedir. Nitekim Acar'ın ifade ettiği üzere (2016, s.104-105) "Başkası'na Ben'in kendinden hareketle, sahip olunan ortaklıklar üzerinden yaklaşılan empati Ben'in bilinciyle sınırlıyken, yerine geçme'de Ben'in kendi özelliklerinin ve dünyasının ötesine açılan bir kapı söz konusudur". Levinas'ın anlayışındaki sorumluluk bir feda edişi ve yerine geçmeyi gündeme getirir. Öyle ki "Ben'in Başkası'nın tüm hatalarından ve onun başına gelebilecek her tür felaketten dahi sorumlu olduğu bu anlayışa göre Ben, adeta seçilmiş gibi, yeryüzünde tekmiş gibi dehşet verici bir yükü yüklenir".

Bauman'ın ahlak anlayışı ve empati açısından özellikle dikkat edilmesi gereken noktalardan biri de "yüz" kavramsallaştırmasıdır. Yüz kavramı bağlamı içinde yani iki kişinin karşılaşması ve benin ötekine yönelik sorumluluk alması açısından anlaşılmalıdır. Levinas'ın öteki ve yüz kavramsallaştırmaları bir tekilliği ve biricikliği ifade eder; "öteki'nin ötekiliği eşsizliğine eşdeğerdir; her Yüz tek ve yegânedir ve eşsizliği kurala özgü gayrişahsîliğe meydan okur". Levinas'ın ahlaki anlayışında "öteki", bütün gündelik şartlar ve rollerden ayrılmış ve statü-sınıf dışı bir nitelik kazanır (Bauman, 2010, s.40-41). Levinas'a göre yüzleşme, (benin başkayla-yüz ile karşılaşması) "ahlaki bilinç"in kendisidir (Levinas, 2010, s.86). Yüz "ötekinin bizi etik sorumluluk haline sokan ve bizi etik davranmaya sevk eden özelliklerini tanımlayan mecazi bir isim" olarak da görülmektedir (Bauman, 2011, s.78).Bauman ötekinin kim olduğunun önemli olmamasını yani ötekinin bütün gündelik şartlardan, mevkilerden, kimliklerden sıyrılmış olmasını yüzün tanımı olarak okuyacağımızı belirtir (Bauman, 1998, s.65). Ayrıca kuralları ve normlarıyla toplumsallaşmanın, kişilerin yüzlerini silmesiyle ve 
sorumluluklarını yok etmesiyle de kalabalıkların empatiyi yok ettiğini belirtir. İki durumda da eylemler bir dış erkin etkisi ile ortaya çıar. Kurallara itaat etmek empatiyi yok ettiği gibi kalabalıktaki kişinin özgüllüğü de kaybolur. Böylece ahlaki benliğin duygusal yetisi devreden çıkar (Bauman, 1998, s.177). Bu bağlamda öteki ile olan ilişkinin niceliği ve niteliği empatinin oluşmasında önemli bir noktadır.

Her ne kadar metaforik kullanımı metaforik olmayan bir kullanımla karşılaştırma hatası olarak görülebilse de benzerlik açısından güncel empati literatürünün de insan yüzüne odaklandığı ve duygusal paylaşım açısından yüze ve yüzleşmeye önem verdiği görülmektedir. De Waal (2014, s.134-22) yüzün kişisel kimliğin özünü oluşturduğunu, vereceğimiz tepkilerin niteliğinde önemli bir değişken olduğunu belirtmektedir. Yüz ifadelerinden etkileniriz, karamsar bir yüz ifadesi bizi karamsarlığa iter. Keyser de (2011, s.140-144) yüzü başkalarının durumlarını algılamada önemli bir aracı olarak görmektedir. Beden hareketleri ve ses tonları ile birlikte yüz kişinin üzgün olduğunu, hasta olduğunu, mutlu olduğunu anlayabileceğimiz yegane aracıdır. Başkalarının yüz hareketlerini gözlemlemek onların içsel durumlarını anlayabilmek için en temel yoldur. Bu noktada De Waal (2014, s.314) evrimsel süreçle bağlantı kurarak empatinin "çağlar aşan bir yetenek olarak kalıtsal özelliklerimize işlemiş bir parçası" olduğunu ve "yüzlere, bedenlere ve seslere olan otomatikleşmiş duyarlılığımız dikkate alındığında, insanların daha en başından beri empati kurduklarını" belirtmektedir. Bununla birlikte De Waal her ne kadar otomatikleşmiş bir duyarlılıktan söz etse de günümüzde yoğun teknoloji kullanımı, evin bir odasına çekilme, bir çok şeyi uzaktan yapabilme başkalarının duygusal halini otomatik ve doğru olarak algılama yeteneğimizi güçleştirmekte böylece empati kabiliyetimiz de azalmaktadır. Goleman (2006, s.81) bu çerçevede günümüz dünyasında sanal uzaklıkların anormalliğine alışıldığını ve uzaklığın empati ve özgecilik duygusunu bastırdığı belirtmektedir. Söz konusu durum özellikle yukarıda belirtilen milgram deneyi ve duyguötesicilik bağlamında da değerlendirilebilir. 


\section{Biz ve Onlar}

Sosyolojide iç grup-dış grup olarak adlandırılan ayrıma benzer şekilde Bauman Sosyolojik Düşünmek başta olmak üzere bir çok eserinde Biz ve Onlar teması ile toplumsal gruplaşmalara dikkat çeker ve ötekileştirme pratiklerini kendine konu edinir. 'Biz' (dostluk) birlikteliği kişinin bağlllık ve güven hissettiği grup üyeleri arasında benzerliğin bulunduğu 'karşılıklı duygu akışı', 'karşılıklı güven', 'ortak bağ', 'dayanışma', 'sevgi ve şefkat'i barındıran bir birlikteliktir. Burada 'onlar' (düşmanlık) ise bunun tamamen zıddı olan bir birlikteliği ifade eder (Bauman, 2004, s.49-53). 'Biz' birlikteliği bir benzerlik duygusunu barındırır. Kişiler, grup içindeki insanların ulaşmaya çalıştığı amaçları olduğu ve bu amaçların, duygusal açıdan kendisine benzediğini varsayar. "Biz" birlikteliği, belirli bir empatiyi, onun gözüyle bakabilmeyi, dert ve sevincin paylaşımını ön plana çıkarır. "Biz" birlikteliğini ifade eden şey, "karşılıklı duygu akışı", "karşılıklı güven", "ortak bă̆", "dayanışma", "sevgi ve şefkat" özelliklerini barındıran ailedir (Bauman, 2004, s.49-53). Biz ve onlar ayrımı toplumsal yaşamdaki birliktelik ve gruplaşmaları ifade ederken kişinin nasıl davranacağı ve ne yapacağına yönelik bilişsel bir harita sağlar. Biz", aynı kaderi paylaşmayı, yoksunluk ve zenginliği birlikte yaşamayı ifade eder. "Onlar" ise bizim felaketlerimiz için dua ederler ve başarılarımızı kıskanırlar. "Biz" herkesin birbiriyle yardımlaşmasını öngörürken "onlar" bizim bitip tükenmemizi beklemektedirler. "Biz" herkesin birbirini anlamasını aynı ve benzer şeyleri düşünüp hissetmesini belirtirken, "onlar" anlaşılmaz ve uğursuz yaratıkları ifade eder (Bauman, 1999, s.102). Biz ve onlar ayrımına empati açısından bakıldığında toplumsal yaşamdaki gruplaşmaların empatiyi nasıl etkilediği önemli bir başlık olarak ön plana çıkmaktadır.

Literatürdeki toplumsal gruplaşma ve empatiye yönelik genel tartışma öncelikle empatinin bilinçli mi yoksa bilinçsiz yapılan bir şey mi olduğuna yöneliktir (Decety ve Moriguchi, 2007; Vignemont ve Singer, 2006). Vignemont ve Singer (2006) güncel araştırmalarından hareketle insanların otomatik (bilinçsiz) olarak empati kurdukları ve bunun da karşı tarafın kim olduğu ile alakalı (yakın biri ya da sevilen biri) olmadığını belirtmektedir. Empati literatürü özellikle ayna nöronların keşfi ile birlikte insan zihninde başkasının deneyimlerini istem dışı hissetmeyi sağlayan 
sinir hücreleri olduğunu ortaya çıkarmıştır. Goleman (2006) ayna nöronların etkinliğinin başkalarının duygularının paylaşımı ile bağlantılı olduğunu, bunun da sonuç olarak yardım etme isteği ile ilişkili olduğunu ifade eder. Güçlü duygusal ifadeler içeren fotoğraflara (tiksinti, neşe, üzüntü) bakıldığında yüz kaslarımızın harekete geçmesi, bir bebeğin ağlamasına ebeveynin verdiği tepki ayna nöronlarla bağlantılıdır. Bu noktada ayna nöronların ortak bir insan doğası oluşturmasına rağmen gruplaşmaların ve şiddetin nasıl oluşabildiği sorusu ortaya çıkmaktadır. Nitekim Iacaboni'ye (2008) göre insanların şiddeti örnek alması, dürtüsel davranışları zihinsel süreçlerden ayırması, kitlesel dinsel ve politik inanışlar bizi nörobiyolojik olarak birbirinize bağlayan bağlardan uzak tutmakta ve insana zalim bir görünüş kazandırmaktadır (Gerdes ve Segal, 2009). Hepimiz sıklıkla kendi kişisel deneyimimiz kültürümüz ve tarihimizi temel alarak belirli gruptaki- koşuldaki kişilere empati gösterme kapasitesine sahibizdir (Statham, 2007). Empatinin başlangıcı bir evrensellik içermekteyse de empatinin kalitesi ve derecesi kişinin kendine verdiği değerden, karşıdaki kişiye ve sürece verdiği değerden etkilenebilmektedir. Kültürel ve sosyal bağlama dikkat çekmek farklılıkların potansiyel sorunlarına karşı hassasiyet ve potansiyel sorunların tanımlanmasına yönelik kişiye sorumluluk vermektedir (Gibbons, 2011). Nitekim empati kuran kişinin hedef kişi ile benzerliğinin olduğunu fark etmesi onu hedef kişinin faydasına olacak eylemleri yapmaya yönlendirmektedir (Hakkanson ve Montgomery, 2003, s.271). Goleman da empati ve özgecilik ilişkisinde benzerliğin ve toplumsal gruplaşmaların etkisine değinmektedir. Goleman'a (2006, s.366) göre "Biz'den biriyle onlar'dan biri arasındaki ilişki, empatiden de yoksundur. Onlar'dan biri Biz'den biriyle konuşmaya yeltenecek olsa, sesi Biz'den birininki kadar tam ya da açık olarak duyulmayacaktır". Bu çerçevede "birisiyle onlar'dan biri olarak ilişki kurduğumuzda, özgeci itkilerimizi silip atarız. Öteki kişi kendilerinden ne kadar farklı olarak tasvir edilmişse, yardımına koşmaya o kadar isteksiz olur".

Rasoal ve arkadaşları toplumsal farklılıklar ve empati konusuna değinerek etno-kültürel empati kavramın dikkat çekmektedirler. Empati araştırmalarına yönelik bir çok teorik çerçeve bulunmasına rağmen bu çerçevelerin etnik ve kültürel empati ile ilgili boyutu sınırlıdır. Etno-kültürel empatinin çekirdek bileşeni farklı kültürden bir kişiyle empati 
kurabilmektir. Başka kültürden bir kişinin benzer sıkıntıları ve amaçları olduğun farkına varılması etno-kültürel empatiyi oluşturmaktadır. Empati araştırmaları kültürlerarası etkileşime önem verse de daha çok benzer etnik ve kültürel arka planı olan kişilerin empati kabiliyetine odaklanmaktadır. Farklı kültürel arka plana sahip bir kişiye empati göstermek aynı kültürel arka planın paylaşıldığı bir kişiye göre daha zor görünmektedir. Örnek olarak günlük etkileşimlerde kültürel farklılıktan dolayı yanlış anlama meydana gelebilir (Rasoal ve ark, 2011). Anlaşılacağı üzere kültürün empatiye etkisi çok önemsenen bir konu değildir. Oysa ki kolektivist bir kültür ile bireyselci bir kültürün birbirini anlaması sorunu önemlidir (Duan ve Hill, 1996). Herkes durumlara ve olaylara yetiştirilmesinden, kişisel ve aile değerlerinden ve yaşadığı önemli olayların şekillendirdiği kendi objektifi aracılığıyla bakar. Belirli bir durum hakkında deneyimimiz olmadığı zaman başkalarının bize söyledikleri, medya, okulda öğrendiklerimiz ya da kitaplarda okuduklarımız gibi dolaylı yollardan edindiğimiz bilgileri kullanırız. Düşünme ve yaşama yollarımız coğrafi konumlar, baskın politik ideoloji, dil, kültür ve ırk, sınıf ve prestij nedeniyle çeşitlidir. Bir grup insan aynı deneyimi yaşasa bile gruptaki her birey deneyimi farklı yollardan deneyimleyebilir (Hardy ve Mawhiney, 2000, s.19). De Turk (2001) kültürler arası empatinin sosyal güç tarafından engellenebildiğini ifade etmektedir. Özellikle hâkim ya da alt gruplar arasında empatinin oluşması aralarındaki güç farklılıklarından dolayı imkânsız görünmektedir (Segal, 2011, s.272). Farklı kültürden insanların birbirlerine empati kuramamasındaki temel engeller, kişinin farklı kültüre yönelik bilgi ve deneyim eksikliği, kişinin kendi kültürü ile farklı bir kültür arasındaki benzerlik ve farklılıkları algılama yeteneği eksikliği olarak vurgulanmaktadır (Rasoal ve ark, 2011, s.9).

Empati, toplumsal gruplaşmalar, benzer insanlara daha çok değer verme ve kültür temaları dikkate alındığında toplum-birey ilişkisi ötekini anlama ve eyleme geçme noktasında dikkat çekmektedir. İnsanlar empatik bir donanıma (ayna nöronlar) sahipse ve bu da onları özgeciliğe yönlendiriyorsa kötülüğün kaynağı nereden geliyor? İnsanlar empatik, özgeci ve ahlaki bir donanıma sahip olsalar da topluluklar bu davranışlardan seçici olarak faydalanmakta ve seçtiği davranışları desteklemektedirler. Doğamız bize empatik olmak ve sosyal olarak sorumlu olmamız için temel araçları vermişse de bu araçları mevcut düzene oturtabilmemiz 
için bir sosyal yönlendirmeye ihtiyacımız vardır (Segal, 2011, s.273) Bauman Hobbes ve Freud'un olumsuz insan doğası tasvirini tersinden görerek Levinas ve Logstrup'a değinir. Toplumsal norm ve kısttlamalar, insanların güven içinde yaşamaları için konulmuş gözükmektedir. Fakat bir yandan insanlar birbirine karşı sınırsız olan sorumluluğunu sınırlamak için de konulmuş olabilir (Bauman, 2010, s.45). "Ahlak, toplumun bir ürünü değildir. Ahlak, toplumun güdülediği -kötüye kullandığı, yönünü değiştirdiği, önünü tıkadığı- bir şeydir" (Bauman, 2007, s.246). Kişinin ahlaki var oluşu toplumsal yaşamın sonucu değil sebebidir. Bu açıdan toplumsal yaşamın kuralları kişinin ahlaki yapısının önünde değil arkasındadır. Bauman a göre kişinin ahlaki olması onun iyi veya kötü olduğunu değil bu iki uç tarafında sürekli bir seçim yapma özgürlügüünün elinde bulundurması ve çeşitli ahlaki çelişkiler içinde kalması demektir (Bauman, 2001, s.10). Bu noktada Bauman'ın müphem insan doğasına paralel bir şekilde evrensel bir insan anlayışının da eleştirildiği görülmektedir. Nitekim Sinclair ve Monk (2005, s.336) empatinin liberal humanist bir dünya görüşünün ürünü olduğunu bu dünya görüşünün de bireyi kendi hayatından sorumlu olarak değerlendirdiğini ve bireyi kendini yönlendiren ve kendini yöneten, kendi yolunu ve kişisel gelişimini belirleyen bir temada kurguladığını belirtir. Bu çerçevede empatinin temel varsayımı insan olarak evrensel insan deneyimlerini paylaşma kabiliyetimizin var olmasıdır. Ancak bu analiz bireyler ve onların sorunlarının büyük kültürel bağlamda oluştuğunu gözden kaçırmaktadır. Bu bakış açısından empati bireyin kendini hissetmesinin doğuştan ve temel doğasına vurgu yaparak kültürel boyutu görmezden gelir.

\section{Sonuç}

Bu çalışmada güncel empati literatürü Bauman'ın görüşleri çerçevesinde değerlendirilmiştir. Bu çerçevede rasyonellik, ahlak, biz ve onlar temaları değerlendirmeye alınmıştır. Rasyonellik ve empati ilişkisinde Bauman'ın duygusal alana kaydığı ve rasyonelliği insanları anlama ve hissetme açısından bir tehlike olarak değerlendirdiği anlaşılmaktadır. Bu noktada kuşkusuz düşüncesini etkileyen Weber, Frankfurt Okulu ve Levinas'in izleri göze çarpmaktadır. Literatürde rasyonellik karşıtlığının postmodern söylemin önemli bir öğesi olduğu vurgulanmaktadır. Bununla birlikte 
Smart'ın (2000, s.337) da belirttiği üzere postmodern söylemin epistemolojik boyutunda yer alan rasyonalizme yönelik eleştirel tutum, açıkça bir irrasyonalizm savunusu değil daha çok yerleşik kabullere ve ortodoks düşünce temellerine karşı verilmiş "rasyonel bir meydan okuma" olarak anlaşılmalıdır. Nitekim Bauman da "aklın kötü kullanımları" (2001, s.214) kavramıyla, modernliğin sorununun rasyonelliğinde değil onun kullanılış biçiminde olduğunun altını çizmektedir. Bu çerçevede aklın insanları anlamaya hizmet edebileceği gibi en fazla insanı en az maliyetle nasıl öldürürüz sorusunun cevabını bulmaya da hizmet edebileceği unutulmamalıdır. Ahlak ve empati tartışması da özellikle özgecilik ve onun sonuçları açısından değerlendirilmelidir. Bauman'ın Levinas'dan miras aldığı ahlaki duruş hissetmeyi ön plana çıkarmaktadır, fakat bu kadar hisseden öznenin durumunun ne olacağı, travmalardan kendini nasıl koruyacağı empati açısından bir tartışma konusu haline gelmektedir. Son olarak toplumsal gruplaşmaların anlamaya etkisi açısından farklılık ve evrensellik tartışması dikkat çekmektedir. Buradaki tartışma "empati evrensel bir insan doğasına hitap ediyorsa farklılıklar ne kadar önemli olabilir ki?" sorusundan "farklılıklarımızı kabul edip anlamadan nasıl birbirimizi anlayabiliriz ki" sorusuna uzanan bir çizgide devam etmektedir.

Sonuç olarak Bauman sosyolojisini disiplinler arası çerçevede kullanmak farklı tartışmaların ortaya çıkması açısından ufuk açıcı bir girişim olarak görülmektedir. Ayna nöronların empati araştırmalarında kullanımı iyimser bir insan doğasına gönderme yapmakta bu durum da Bauman'ın sorumluluk temelli incinen-hassas insan perspektifi diyebileceğimiz anlayışı ile uyum göstermektedir. Özellikle ahlaki bakış açısının güncel empati-özgecilik-sempati-merhamet yani birlikte yaşamanın imkanı konuları üzerine yapılan araştırmalar ve çalışmalarla değerlendirilmesi hem psikoloji hem de sosyoloji açısından literatüre katkı sağlayacaktır. Toplumsal gruplaşmalar açısından ise etno-kültürel empati çalışmalarında Bauman'ın biz ve onlar, yabancılar kavramsallaştırmaları teorik bir çerçeve olarak kullanılabilir. 


\title{
EXTENDED ABSTRACT
}

\section{The Concept of Empathy Through the Perspective of Zygmunt Bauman}

\author{
Doğa Başer - Mehmet Kırlığlu - Huriye İrem Kalaycı Kırlığlu \\ Selçuk University - Necmettin Erbakan University
}

Understanding and feeling the other have become one of the main pursuits and dead ends of social sciences. The multidisciplinary conception of empathy is the ability of envisioning of what the other thinks and feels. Considering the fact that empathy emphasizes understanding of feelings and thoughts, Bauman gives also a strong emphasis on emotions. This study evaluates the current literature of empathy within the context of Bauman's ideas. The themes of rationality, morality, us and them are evaluated in this context. Within the theme of rationality, Bauman's criticism of rationality evaluated depending on the fact that empathy has both cognitive and emotional aspects. Similarly, the relation between empathy and rationality is formed with which the importance of knowledge and feeling are mentioned in understanding the other. One of the basic elements of rationality is "to reach the right results quickly and cheaply". In the Bauman perspective, reason is the ability of human to know, predict, calculate. In terms of empathy and rationality, especially in the context of the genocides of the Second World War, it is stated that rationality is a dangerous phenomenon in terms of desensitization. The feelings or insensitivity of the Nazi officers is an issue that Bauman often deals with. In the theme of morality, Levinas' understanding of morality, which is the foundation of Bauman's morality, is used to analyse the possibility of understanding the other and its relation to altruism. Nowadays, empathy is seen as a source of helping the other and altruistic behavior. Bauman associates morality with social context. According to him, "moral behavior can only be understood in the conditions of being with others, that is, in the social context." The discussions of empathy also underlies the importance of human beings' limitations of themselves to protect themselves from being negatively affected while they are trying to understand the other. This 
conception of altruism includes human beings' giving priority to the other before themselves. For the themes of we and the other, the scope of influence of grouping in social life for understanding the other, and what kind of relation might be between understanding of the other and being similar, close and different are the subjects that are emphasized.

In this study, the current literature of empathy was evaluated within the framework of Bauman's views. In this context, rationality, morality, us and them themes are evaluated. In the relationship of rationality and empathy, it seems that Bauman shifted into the emotional field and viewed rationality as a danger to people to understand and feel. Undoubtedly, the traces of Weber, Frankfurt School and Levinas are striking. In the literature, it is emphasized that non-rationality is an important element of postmodern discourse. However, as Smart argues, the critical attitude towards rationalism in the epistemological dimension of postmodern discourse should not be understood as an explicit defense of irrationalism, but rather as a "rational challenge" against established assumptions and orthodox thought foundations. In fact, Bauman underlines that the problem of modernity is not in its rationality but in the form of its use with the concept of "misuses of mind". In this context, it should be remembered that the mind can serve to understand people as well as to find the answer to the question of how to kill the most people at the lowest cost. The discussion of morality and empathy should also be considered, especially in terms of altruism and its consequences. The moral stance that Bauman inherited from Levinas emphasizes the feeling, but what the situation of the subject feeling so much will be and how it will protect itself from traumas becomes a matter of debate in terms of empathy. Finally, the debate on difference and universality in terms of the effect of social groupings on understanding is remarkable. The discussion here continues along the line from "how important can the differences be if empathy addresses a universal human nature?to "how can we understand each other without accepting and understanding our differences?" As a result, using Bauman sociology in an interdisciplinary framework is seen as a horizon initiative for the emergence of different debates. The use of mirror neurons in empathy research refers to an optimistic human nature, which is in line with Bauman's understanding of what we might call a responsibility-based hurt-sensitive human perspective. In particular, the evaluation of the 
moral point of view through research and studies on current empathyaltruism-sympathy-compassion, the possibility of living together with the research and studies on the issues will contribute to the literature in terms of both psychology and sociology. In terms of social groupings, Bauman's us and them conceptions of stranger can be used as a theoretical framework in ethno-cultural empathy studies.

\section{Kaynakça / References}

Acar, M.A. (2016). Levinas'ta aşkınlık düşüncesine giriş. Kaygı Uludağ Üniversitesi Fen-Edebiyat Fakültesi Felsefe Dergisi, 27, 93-110.

Apaydın, E. (2006). Levinas felsefesinde öznelik ve öteki problem. (Yayınlanmamış yüksek lisans tezi). Ankara Üniversitesi Sosyal Bilimler Enstitüsü Felsefe Tarihi Anabilim Dalı, Ankara.

Bauman Z. (2011). Modernite, kapitalizm, sosyalizm. İstanbul: Say Yayınevi.

Bauman, Z. (1998). Postmondern etik. İstanbul: Ayrıntı Yayınları.

Bauman, Z. (1999) Culture as praxis. London: Sage Publications Ltd.

Bauman, Z. (2000). Ölümlülük ölümsüzlük ve diğer hayat stratejileri. İstanbul: Ayrintı Yayınları.

Bauman, Z. (2001). Parçalanmış hayat postmodern ahlak denemeleri. İstanbul: Ayrıntı Yayınları.

Bauman, Z. (2003). Modernlik ve müphemlik. İstanbul: Ayrıntı Yayınları.

Bauman, Z. (2004). Sosyolojik düşünmek. İstanbul: Ayrıntı Yayınları.

Bauman, Z. (2005). Bireyselleşmiş toplum. İstanbul: Ayrıntı Yayınları.

Bauman, Z. (2007a). Consuming life. USA: Polity Press.

Bauman, Z. (2007b). Modernite ve holocaust. İstanbul: Versus Kitap.

Bauman, Z. (2009). Akışkan aşk insan ilişkilerinin kırılganlığına dair. İstanbul: Versus Kitap.

Bauman, Z. (2010). Etiğin tüketiciler dünyasında bir şansı var mı? Ankara: De Ki Yayınevi.

Bauman, Z. (2017). Akışkan modernite. İstanbul: Can Yayınları.

Cosmovici, I. (2016). The "Embedding metaphor". The emotional and sensitive dimensions of zygmunt bauman's scientifical metaphors.Journal of Experiential Psychotherapy, 19(3), 20-29. 
Crone, M. (2008). Bauman on ethics-intimate ethics for a global world?M.H. Jacobsen, P. Poder (Der.), The sociology of Zygmunt Bauman challenges and critique (ss. 155-171). Hampshire: Ashgate Publishing Ltd.

De Waal, F.(2014). Empati çă̆ı. Ankara: Akıl Çelen Kitaplar.

Decety, J., Moriguchi, Y.(2007). The empathic brain and its dysfunction in psychiatric populations: implications for interventions across clinical conditions. BioPyschoSocialMedicine, 1, 1-22.

Dökmen, Ü.(1998). İletişim çatışmaları ve empati: Sanatta ve günlük yaşamda. İstanbul: Sistem yayıncılık.

Gair, S.(2011). Creating spaces for critical reflection in social work education: learning from a classroom-based empathy project. Reflective Practice, 12(6), 791-802.

Gerdes, K. E.(2011). Empathy, sympathy, and pity: 21st-century definitions and implications for practice and research. Journal of Social Service Research, 37(3), 230-241.

Gerdes, K. E., Segal, E. A.(2009). A social work model of empathy. Advances in Social Work, 10(2), 114-127.

Gerdes, K. E., Segal, E. A., Lietz, C. A.(2010). Conceptualising and measuring empathy. British Journal of Social Work, 40, 2326-2343.

Gibbons, S. B.(2011). Understanding empathy as a complex construct: A review of the literature. Clinical Social Work Journal, 39, 243-252.

Goleman, D.(2006). Sosyal zeka insan ilişkilerinin yeni bilimi. İstanbul: Varlık Yayınları.

Gruen A. (2006). Empatinin yitimi kayıtsızlık politikası üzerine. İstanbul: Çitlembik Yayınları.

Hakansson, J., Montgomery, H. (2003). Empathy as an interpersonal phenomenon. Journal of Social and Personal Relationships, 20(3), 267-284.

Hardy, S., Mawhiney, A. M. (2000). Diversity in social work practice. S. Nancy, S. Karol, G. Bernie(Der.),Challanges for social work students (ss. 19-34). Toronto: Canadian Scholars' Press.

Hookway, N. (2016). Zygmunt Bauman's moral saint: Reclaiming self in the sociology of morality. Acta Sociologica,60(4), 358-367.

Junge, M. (2001). Zygmunt Bauman's posioned gift of morality.British Jorunal of Sociology, 52(1), 105-119.

Karadağ, E., Mutafçılar, I. (2009). Prososyal davranış ekseninde özgecilik üzerine teorik bir çözümleme. Felsefe ve Sosyal Bilimler Dergisi, 8, 4170 . 
King, S. H. (2011). The structure of empathy in social work practice. Journal of Human Behavior in the Social Environment, 21, 679-695.

Kumar, K. (2004). Sanayi sonrası toplumdan post-modern topluma çă̆daş dünyanın yeni kuramları. Ankara: Dost Kitabevi.

Levenson, R. W., Ruef, A. M.(1992). Empathy: a physiological substrate.Journal of Personality and Social Psychology, 63(2), 234-246.

Levinas, E. (2005) Zaman ve başka. İstanbul: Metis Yayınları.

Levinas, E. (2006). Ölüm ve zaman. İstanbul: Ayrıntı Yayınevi.

Levinas, E. (2010). Sonsuza tanıklık. İstanbul: Metis Yayınları.

McCann, I. L., Pearlman, L. A. (1990). Vicarious traumatization: A framework for understanding the psychological effects of working with victims. Journal of Traumatic Stress, 3(1), 131-149.

Mestrovic, S. G. (1999). Duyguötesi toplum. İstanbul : Ayrıntı Yayınları.

Morgan, W. D., Morgan, S. T.(2005). Cultivating attention and empathy. C. K. Germer, R. D. Siegel (Der.), Mindfulness and psychotherapy(ss. 79-90). Fulton PR, New York: Guilford Press.

Rasoal, C., Eklund, J., Hansen, E. M.(2011). Toward a conceptualization of ethnocultural empathy. Journal of Social, Evolutionary and Cultural Psychology, 5(1), 1-13

Richards, S., Ruch, G., Trevithick, P. (2005). Communication skills training for practice:The ethical dilemma for social work education.Social Work Education: The International Journal, 24 (4), 409-422.

Rogers, C.(2011). Kişi olmaya dair: Bir terapistin gözüyle psikoterapiye giriş. İstanbul: Okyanus Yayınları.

Segal, E. A. (2007). Social empathy: A new paradigm to address poverty. Journal of Poverty, 11(3), 65-81.

Segal, E. A.(2011). Social empathy: A model built on empathy, contextual understanding, and social responsibility that promotes social justice. Journal of Social Service Research, 37, 266-277

Sinclair, S. L., Monk, G., (2005). Discursive empathy: a new foundation for therapeutic practice. British Journal of Guidance $\mathcal{E}$ Counselling, 33(3), 333-349

Smart, B. (2000). Postmodern toplum teorisi. M. Küçük (Der.), Modernite versus postmodernite (ss. 317-366). Ankara: Vadi Yayınları.

Statham, D.(2007). Models of assesment. L. Joyce (Der.), Handbook for practice learning in social work and social care (ss. 101-114). USA: Jessica Kingsley Publishers. 
Tarhan, N.(2013). Toplum psikolojisi. İstanbul: Timaş Yayınları.

Thomas, J. T., Otis, M. D.(2010). Intrapsychic correlates of professional quality of life: Mindfulness, empathy and emotional separation. Journal of the Society for Social Work and Research, 1(2), 83-98.

Turan, H. (2016). Levinas'ta fenomenoloji ve başkalık. V. Türkiye'de Lisansüstü Çalışmalar Kongresi (ss. 223-236), Isparta.

Vignemont, F. D., Singer, T.(2006). The empathic brain: How, when and why? Trends in Cognitive Sciences, 10(10), 435-440.

\section{Kaynakça Bilgisi / Citation Information}

Başer, D., Kırlığlu, M. ve Kalayc1-Kırlıŏlu, H. İ. (2019). Empati kavramına bauman çerçevesinden bir bakış. OPUS-Uluslararası Toplum Araştırmaları Dergisi, 13(19), 2321-2344. DOI: 10.26466/opus.570549 